\title{
Barn med nevrodegenerativ sykdom
}

\author{
Nevrodegenerative sykdommer hos barn er ofte autosomalt recessivt nedarvet. De fleste \\ tilfellene er metabolske, der inngifte er en viktig risikofaktor. Diagnostikken kan være svært \\ krevende. Tap av motoriske, kognitive og sosiale ferdigheter er vanlig. Det kreves stor innsats \\ fra hjelpeapparatet - 15-30 fagpersoner kan være engasjert rundt én pasient. For et økende \\ antall sykdommer finnes det nye og dyre behandlingsformer.
}

\author{
Øivind Juris Kanavin \\ Barneavdeling for nevrofag \\ Kvinne- og barnklinikken \\ Oslo universitetssykehus, Ullevål \\ Petter Strømme \\ petter.stromme@medisin.uio.no \\ Barneavdeling for nevrofag \\ Kvinne- og barnklinikken \\ Oslo universitetssykehus, Ullevål \\ 0407 Oslo \\ og \\ Institutt for klinisk medisin \\ Det medisinske fakultet \\ Universitetet i Oslo
}

Selv om nevrodegenerative sykdommer hos barn innebærer høy mortalitet og morbiditet, er de ikke lenger uhelbredelige, da kausalt rettet behandling etter hvert er blitt tilgjengelig (1). Likevel representer disse sykdommene en stor belastning for alle involverte. En families erfaringer med påkjenningene som oppstår i forløpet av å ha et barn med nevrodegenerativ sykdom er beskrevet nedenfor.

Pasienten. Gutten, som nå er i tenårene, har hele tiden vokst lite. Han har mikrokefali, med hodeomkrets $5 \mathrm{~cm}<2,5$-prosentilen, og et «gammelmannsaktig» utseende, med uthulte øyne og lite subkutant fettvev. Høyden er $110 \mathrm{~cm}$, som er $24 \mathrm{~cm}<2,5$-prosentilen og tilsvarer gjennomsnittshøyden for en femåring. Gastrostomi førte til en betydelig bedring av ernæringssituasjonen, men hadde trolig ikke tilsvarende gunstig effekt på høydetilveksten. Han satt ved åtte måneders alder og gikk med støtte 16 måneder gammel, men oppnådde ikke selvstendig gange. Hørselen begynte å svikte ved to års alder, og han fikk høreapparat. Det ble etter hvert åpenbart at han var mentalt retardert. $31 / 2$ år gammel skåret han tilsvarende 16månedersnivå på en ferdighetstest. Ved fire års alder begynte han å miste motoriske ferdigheter, og en kombinasjon av cerebellar ataksi, demyeliniserende polynevropati og spastisitet gjorde ham fullstendig avhengig av rullestol.

Gutten er i kontakt med en lang rekke spesialister - ortoped, ryggortoped, barnekirurg, øyelege, tannlege, øre-nese-halslege, gastroenterolog, barnenevrolog, audiopedagog, stomisykepleier og ernæringsfysiolog. Førstelinjetjenesten er involvert med bl.a. fastlege, fysioterapeut, ergoterapeut og sosionom. I tillegg kommer assistanse fra personell på skolen og avlastningshjelp for foreldrene. Samordningen av innsatsen har vært så krevende at faren mistet arbeidet på grunn av for høyt fravær for å følge opp konsultasjonene.

Situasjonen blir ikke mindre komplisert av at familien har ikke-vestlig innvandrerbakgrunn - det er utfordringer vedrørende norsk språk og kultur.

Noen år senere fødte moren en gutt til med nøyaktig samme symptomutvikling og funn, slik at familien har to barn med nevrodegenerativ tilstand - i tillegg til sine friske barn. Til tross for inngående undersøkelser på sykehus ble årsaksdiagnosen først stilt flere år etter guttene var født. Gjennombruddet kom ved bruk av internasjonale kontaktnettverk og etter relevante cerebrale MR- og CT-undersøkelser med påfølgende cellebiologiske og genetiske analyser.

\section{Forekomst -}

\section{inngifte som risikofaktor}

Selv om de hver for seg er sjeldne, er nevrodegenerative sykdommer hos barn relativt hyppig forekommende samlet sett. Klinisk består de av progredierende encefalopatier (som i hovedsak rammer hjernen) og en gruppe med hovedsakelig nevromuskulære symptomer. Det finnes få studier der man har kartlagt forekomsten. I en undersøkelse utgått fra Oslo universitetssykehus (Aker og Ullevål sykehus og Rikshospitalet) fant man totalt 84 Oslo-barn med progredierende encefalopati født i årene 1985-2004. Til sammen representerte disse 28 forskjellige diagnoser, hovedsakelig autosomalt recessive sykdommer, men hos fire pasienter (5\%) var det X-bundet arv.
Insidensraten, som ble beregnet til 6,4 per 100000 personår, var stabil gjennom observasjonsperioden (fig 1) (2). Den kumulative insidensen på 0,6 per 1000 i Oslo var sammenliknbar med insidensen $i$ en tidligere studie fra Vest-Sverige (3) og like hyppig som medfødt hydrocephalus (4) eller nevralrørsdefekter (5). Vårt materiale fra Oslo viste videre at progredierende encefalopati hos barn var sju ganger så vanlig hos barn av pakistanske foreldre som hos barn av norske (6). Forklaringen på den økte risikoen var høy forekomst av inngifte hos foreldre med bakgrunn fra Pakistan. Pakistanske foreldre som er fetter og kusine har 11 ganger så høy risiko for å få et barn med progredierende encefalopati som et par med norsk etnisk bakgrunn (fig 2) (6).

I Vest-Europa og Nord-Amerika er det skepsis til inngifte, og det er forbudt ved lov i flertallet av delstatene i USA. I en oversiktsartikkel om medisinske konsekvenser av denne praksisen peker Bittles \& Black (7) på at i rurale strøk der prevalensen av inngifte er 50-60\%, det gjelder f.eks. noen områder i Pakistan (8), oppveier de sosiale fordelene ved nært slektskap mellom foreldrene de biologiske ulempene. Et barn med medfødt autosomalt recessiv sykdom vil der kanskje ikke leve lenge fordi medisinsk behandling ikke er aktuelt på grunn av ressursmangel. I Vest-Europa og NordAmerika er forholdene annerledes. Der vil det være større sannsynlighet for at barnet skal leve opp, men det vil være avhengig av livslang behandling eller støtte. I Norge, i motsetning til i Storbritannia, er prevalensen av inngifte blant ikke-vestlige innvandrere synkende, og bare $16,7 \%$ av pakistanske kvinner født i Norge er gift med sin fetter (9). Synkende prevalens av inngifte blant innvandrere på tross av økt ikke-vestlig innvandring kan forklare hvorfor insidensen av progredierende encefalopati i Oslo har holdt seg stabil (fig 1).

I alle tilfeller der det er mistanke om nevrodegenerativ sykdom, uansett inngiftestatus, henvises foreldrene til genetisk avdeling for informasjon om gjentakelses- 


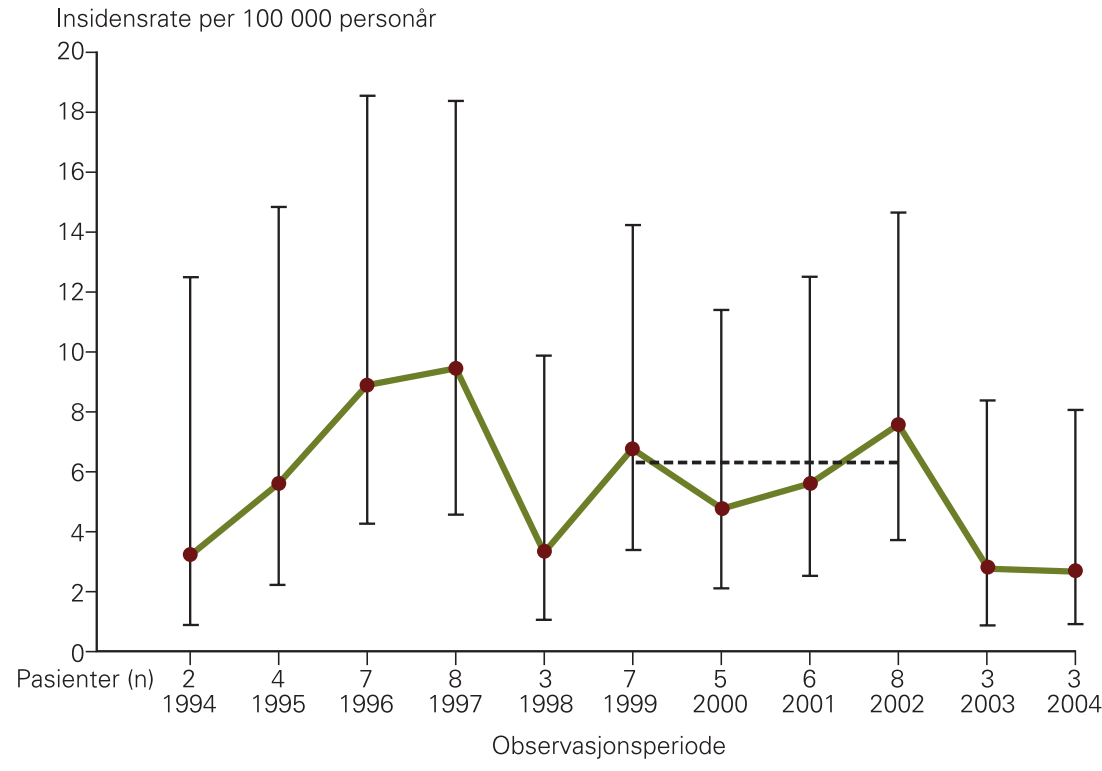

Figur 1 Insidensraten av progredierende encefalopati hos Oslo-barn i alderen 0-15 år var stabil i perioden 1994-2004 (2). 95 \% konfidensintervall (KI) for hvert års insidensrate er indikert med vertikal linje. Mellom 1999 og 2002 var insidensraten 6,13 per 100000 personår under risiko. Beregningen av personår, som var basert på antall fødsler per år, var tilnærmet riktig frem til 1999, mens antall nye sykdomstilfeller etter 2002 kan være underestimert fordi enkelte, spesielt barn født i 2003, ikke hadde rukket å utvikle sykdomssymptomer. Årene 1999-2002 (den stiplede horisontale linjen) var derfor den mest representative perioden for insidensberegningen

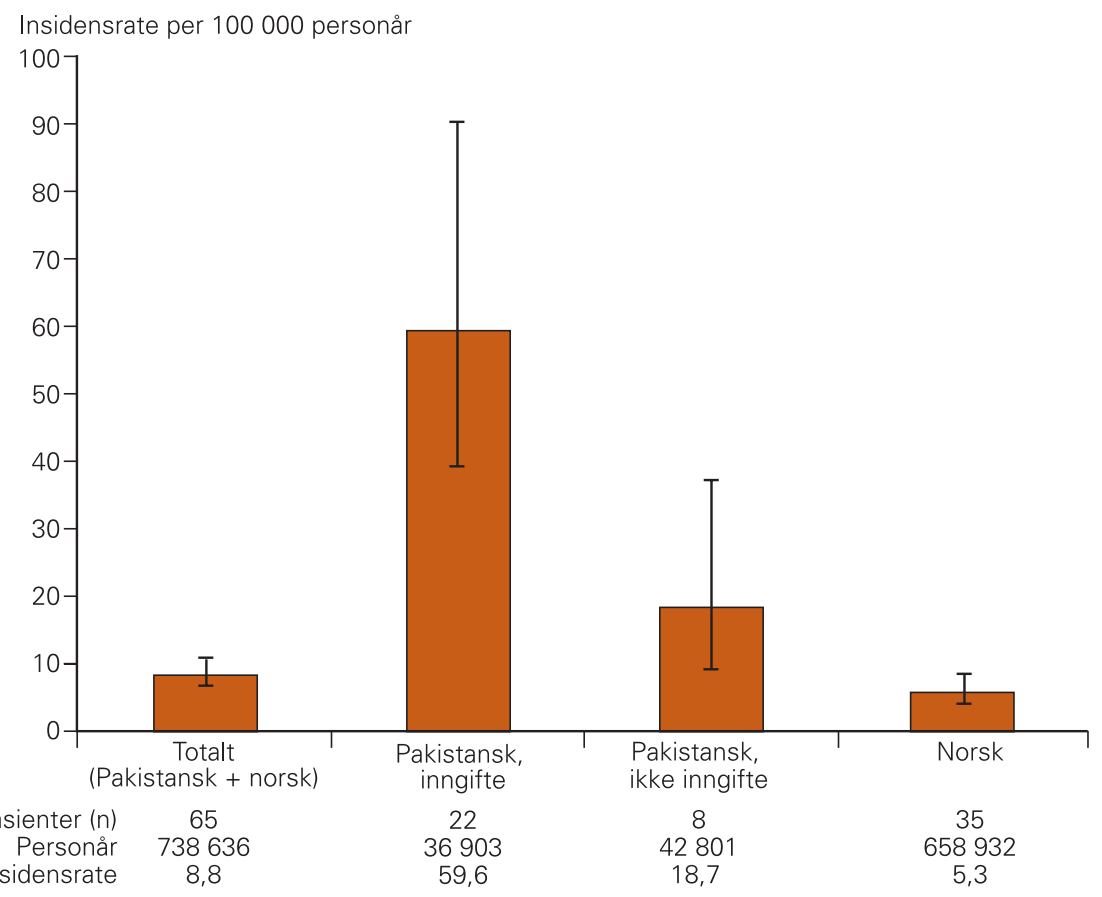

Figur 2 Insidensraten av progredierende encefalopati ble målt hos pakistanske og norske barn i henhold til foreldrenes inngiftestatus (6). Følgende insidensrateratioer kunne beregnes: barn av inngiftede foreldre med pakistansk bakgrunn (pakistansk, inngifte) versus norske barn (norsk) = 11,2; barn av inngiftede foreldre med pakistansk bakgrunn versus barn av ikke-inngiftede foreldre med pakistansk bakgrunn (pakistansk, ikke inngifte) = 3,2; barn av ikke-inngiftede foreldre med pakistansk bakgrunn versus norske barn $=3,5$. Inngiftet er her definert som fetter-kusine-ekteskap. De vertikale linjene indikerer $95 \%$ konfidensintervall. Verdiene viser at inngifte er en risikofaktor for progredierende encefalopati. I tillegg er pakistansk bakgrunn en separat risikofaktor. Årsakene til dette er komplekse og bunner blant annet i en inngiftepraksis, som er fjernere enn fetter-kusine-ekteskap, i klaner og brorskap (biraderi) i rurale strøk. Figuren er hentet fra Strømme og medarbeideres artikkel (6). ( 2010, Elsevier. Gjengitt med tillatelse risikoen og mulig fosterdiagnostikk. Slik henvisning er rutine både i tilfeller der diagnosen er stilt, men også i tilfeller der årsaken er ukjent.

\section{Symptomer og prognose}

Tap av psykomotoriske ferdigheter hos barn kan være vanskelig å fange opp, spesielt i 1-2 års alder, da den normale utviklingen skjer raskt. Sykdommer med hovedsakelig affeksjon av hvit hjernesubstans debuterer gjerne med motoriske problemer på grunn av spastisitet. En fellesnevner for sykdommer der grå substans først blir angrepet, er epilepsi og demensutvikling. Tap av syn og hørsel og utfall fra andre organsystemer (lever, hjerte, nyre og skjelett) forekommer også ved en rekke metabolske tilstander.

Ved noen sykdommer varierer den fenotypiske utformingen med hvilken alder symptomene debuterer. Et eksempel på dette er Niemann-Picks sykdom type $\mathrm{C}$ (NPC), der debut i voksen alder er kjennetegnet av psykiatriske symptomer, mens samme genmutasjon gir en infantil eller tidlig juvenil form, som regel med tidlig død (10). I Oslo-studien var dødeligheten ved progredierende encefalopatier hos barn $36,9 \%$ etter en gjennomsnittlig oppfølgingstid på 8,5 år (11). Den korteste overlevelsen ble observert hos barn med metabolsk sykdom som debuterte i neonatalperioden.

\section{Utvidet screening?}

Å stille en riktig etiologisk diagnose ved nevrodegenerative sykdommer hos barn er viktig av mange grunner. Samtidig kan det ofte være en krevende og langvarig prosess. Undersøkelse med cerebral MR-bildefremstilling (MR «imaging»; MRI) kombineres stadig oftere med MR-spektroskopi (MRS). Ved hjelp av sistnevnte undersøkelse fremstilles de vanligste metabolitter i hjernen, og den er nyttig i diagnostikken innenfor et bredt spektrum av metabolske og degenerative tilstander (12). Ett eksempel på kombinert MRI- og MRS-undersøkelse er vist i figur 3 (13). Selv etter nitid utredning med cerebral MR, biokjemiske analyser (avdeling for genetisk biokjemi, Rikshospitalet, og avdelingen for klinisk kjemi ved Sahlgrenska Universitetssjukhuset, Göteborg) og molekylærgenetiske analyser (sekvensering av ett eller flere gener eller screening av et utvalg mutasjoner) forblir en stor andel av pasientene uten etiologisk diagnose. I Oslo-studien utgjorde gruppen udiagnostiserte $20 \%$ av pasientene, på tross av at de var blitt drøftet $i$ et panel med utenlandske eksperter (2). Foto, video og nye digitale medier som Internett og elektroniske syndromdatabaser har imidlertid lettet det diagnostiske arbeidet vesentlig.

Stadig nye behandlingsmuligheter aktualiserer viktigheten av en presis diagnose ytterligere. Behandlingen bør settes inn før sentralnervesystemet påføres irreversibel 


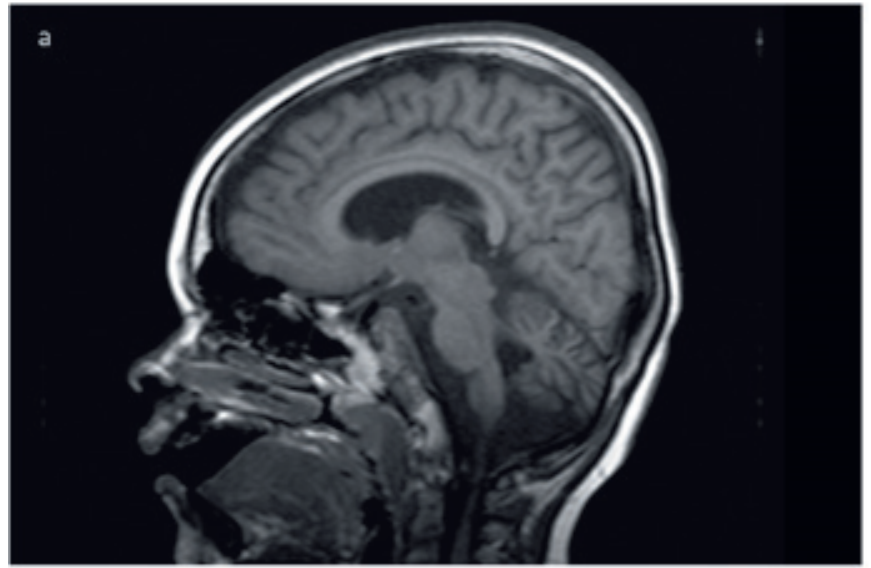

C

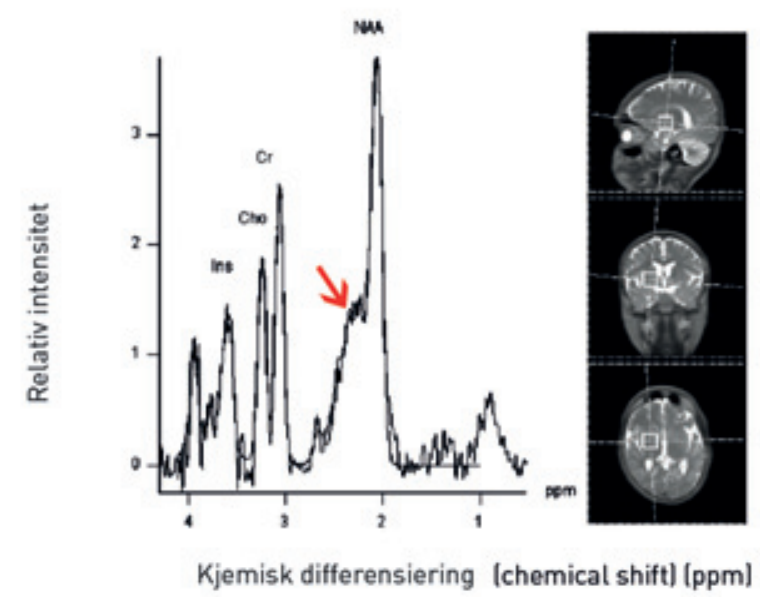

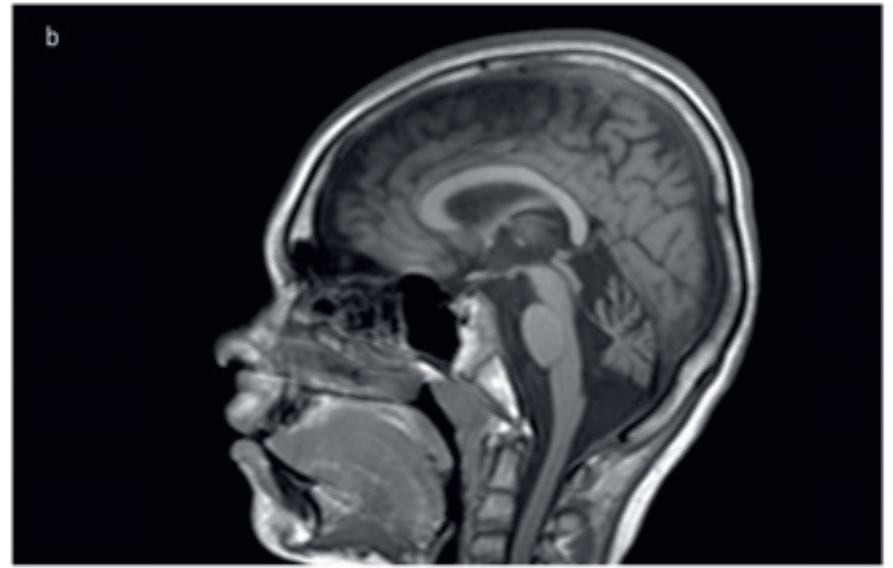

d

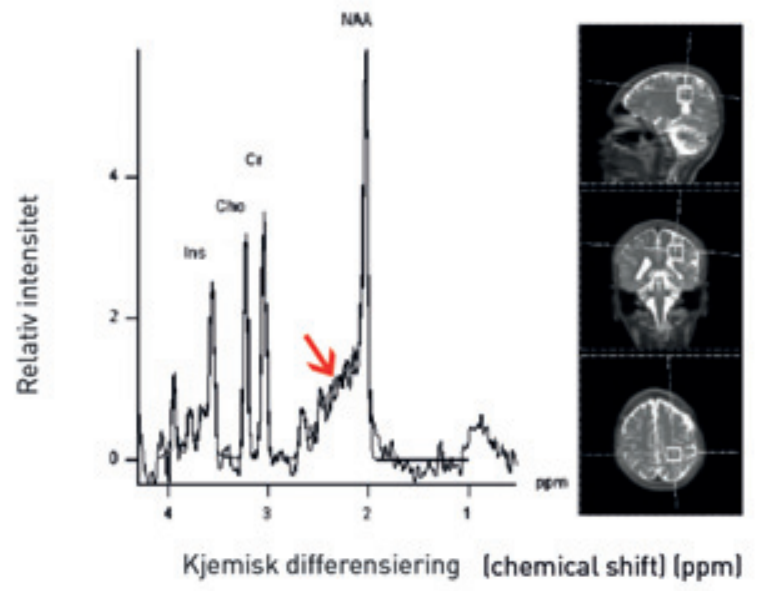

Figur 3 a, b) Magnetisk resonans (MR) bildefremstilling med sagittale snitt og c, d) magnetisk resonans-spektroskopi (MRS). a) Cerebellar atrofi hos en fire år gammel gutt, b) ytterligere cerebellar atrofi hos den samme gutten tre år senere (13). Tap av nevroner, i dette tilfellet i cerebellum, vil kvalifisere for en diagnose innenfor gruppen av nevrodegenerative sykdommer. c) Økt forekomst av glutamat-glutamin-kompleks (pil) i basalgangliene, d) normal forekomst av glutamat-glutamin-kompleks (pil) i dyp cerebral hvit substans. Spektraltoppene for de øvrige metabolittene insitol (Ins), cholin (cho), kreatin (Cr) og n-acetylaspertat (NAA) er angitt. Det er forholdet mellom høyden på toppene som er avgjørende for tolkingen. c) Forhøyet glutamat-glutamin-forekomst indikerte i dette tilfellet en feil i nevrotransmittermetabolismen i de basale ganglier hos pasienten. Figuren hentet fra Gillfillan og medarbeideres artikkel (13). () 2008, Elsevier. Gjengitt med tillatelse

skade. I Norge screenes i dag nyfødte for fenylketonuri og hypotyreose. Med tandemmassespektrometrimetoden (MS/MS) kan langt flere tilstander oppdages tidlig. I en del industrialiserte land har man allerede mange års erfaring med å screene for flere titall forskjellige tilstander der medisinsk intervensjon vil være nyttig (14). Et nytt norsk nyfødtscreeningprogram som inkluderer 19 sykdommer er foreslått av det nasjonale rådet for kvalitet og prioritering $i$ helsetjenesten. Problematiske sider ved en slik utvidelse av nyfødtscreeningen, blant annet hensynet til frivillighet og reelt samtykke, har vært drøftet i Tidsskriftet (15).

\section{Mange involverte - \\ manglende koordinering}

Slik sykehistorien over illustrerer kan oppfølging av nevrodegenerativ sykdom hos barn være svært krevende. Den omfattende kontaktflaten - ikke bare med helsepersonell, men med alle typer hjelpere - stiller store krav til samarbeid. At over 10-15 fagpersoner i spesialisthelsetjenesten til enhver tid er involvert rundt én pasient er heller normen enn unntaket! I tillegg er det et like stort antall hjelpere i førstelinjetjenesten. Hvis man legger til at familiene til flere av disse pasientene ikke har røtter i Norge og ikke har norsk som morsmål, begynner bildet å bli enda mer realistisk.

Det er i praksis svært vanskelig å få til en helt tilfredsstillende koordinert oppfølging. Siden sykdommen kan endre seg raskt, kan det være vanskelig å forutsi den enkelte pasients behov. Barnehabiliteringen er ansvarlig for koordineringen av det medisinske tilbudet til pasienten og familien. Et sentralt poeng i oppfølgingen er å sikre at de involverte aktørene kontinuerlig blir oppdatert om situasjonen. Enkle rutiner, som det at man alltid må sende kopi av polikliniske notater til foresatte og fastlege, svikter lett. Individuell pasientplan med pasientkoordinator i førstelinjetjenesten er svært nyttig. Fastlegen er en uvurderlig samarbeidspartner. Stadig dokumentasjon når det gjelder sosiale rettigheter, omsorgslønn, pleiepenger og hjelpemidler er belastende for en familie som er hardt presset fra før. Frambu helsesenter er et landsdekkende kompetansesenter for sjeldne funksjonshemninger og har en viktig rolle i å støtte pasienten og dens familie.

\section{$\mathrm{Ny}$, kostbar behandling}

Bortsett fra beinmargstransplantasjon, som har vært et behandlingstilbud i flere tiår ved utvalgte lysosomale avleiringssykdommer som Hurlers syndrom (mukopolysakkaridose type 1) (16), har behandlingsmulighetene vært få. Enzymerstatningsterapi (enzyme replacement therapy, ERT) har vært brukt siden tidlig i 1990-årene for enkelte lysosomale sykdommer, slik som Gauchers sykdom (17) og Fabrys sykdom (18), og behandlingsalternativer for andre tilstander har kommet til nesten hvert år. 
Også substratreduksjonsterapi (SRT) er et alternativ ved lysosomal sykdom (19), og i noen tilfeller kan substratreduksjonsterapi og enzymerstatningsterapi kombineres (20).

Det har vist seg at beinmargstransplantasjon kan stabilisere den demyeliniserende prosessen ved X-bundet adrenoleukodystrofi (X-ALD) hvis man starter behandlingen tidlig, helst før debut av nevrologiske symptomer (21). Nylig ble det rapportert gode resultater etter en mer raffinert form for genterapi hos to slike pasienter med normal intelligenskvotient og motorikk, men med demyeliniserende forandringer i hjernen (22). Ekstraherte hematopoetiske stamceller fra de to ble infisert med en virusvektor som var innsatt med villtypegenet for X-ALD. De transuderte (infiserte) stamcellene som ble injisert tilbake, påvirket gliacellene i hjernen slik at demyeliniseringen stanset opp. Motorikk og intelligenskvotient var fortsatt på normalt nivå etter to og tre års observasjonstid (22).

Bedrede behandlingsmuligheter er et sterkt argument for å innføre utvidet nyfødtscreening i Norge. Felles for de fleste nye behandlingsstrategier er at de isolert sett er kostbare. Enzymerstatningsterapi og substratreduksjonsterapi er livslang behandling. Det reiser spørsmålet om vi har råd til denne type behandling. For eksempel koster substratreduksjonsterapi med Miglustat ved NiemannPicks sykdom type $\mathrm{C}$ hos en voksen pasient 2 millioner kroner i året (Torbjørn Ritzler, Actelion, Sverige, personlig meddelelse). Prisen er avhengig av pasientens vekt og blir derfor lavere for barn. Ved en kostnad-nytteanalyse må man imidlertid ta med i regnestykket potensielle besparelser gjennom reduserte offentlige utgifter til støttebehandling hvis pasienten responderer gunstig på behandlingen.

Oppgitte interessekonflikter: Ingen

Pasientens pårørende har gitt samtykke til at artikkelen blir publisert.

\section{Litteratur}

1. Newton CR, Neville BG. Paediatric neurology: advances on many fronts. Lancet Neurol 2009; 8: $14-5$

2. Stromme P, Kanavin OJ, Abdelnoor M et al. Incidence rates of progressive childhood encephalopathy in Oslo, Norway: a population based study. BMC Pediatr 2007: 7: 25

3. Uvebrant P, Lanneskog K, Hagberg B. The epidemiology of progressive encephalopathies in childhood. I. Live birth prevalence in west Sweden. Neuropediatrics 1992; 23: 209-11.

4. Persson EK, Hagberg G, Uvebrant P. Hydrocephalus prevalence and outcome in a population-based cohort of children born in 1989-1998. Acta Paediatr 2005: 94: 726-32.

5. Lary JM, Edmonds LD. Prevalence of spina bifida at birth - United States, 1983-1990: a comparison of two surveillance systems. MMWR CDC Surveill Summ 1996; 45: 15-26.

6. Stromme P, Suren P, Kanavin OJ et al. Parental consanguinity is associated with a seven-fold increased risk of progressive encephalopathy: a cohort study from Oslo, Norway. Eur J Paediatr Neurol 2010: 14: 138-45.

7. Bittles $A H$, Black ML. Evolution in health and medicine Sackler colloquium: consanguinity, human evolution, and complex diseases. Proc Nat Acad Sci USA 2010; 107 (suppl 1): 1779-86.

8. Hussain R, Bittles AH. The prevalence and demographic characteristics of consanguineous marriages in Pakistan. J Biosoc Sci 1998; 30: 261-75.

9. Grjibovski AM, Magnus P, Stoltenberg C. Decrease in consanguinity among parents of children born in Norway to women of Pakistani origin: a registrybased study. Scand J Public Health 2009; 37: 232-8.

10. Vanier MT, Millat G. Niemann-Pick disease type C Clin Genet 2003; 64: 269-81.

11. Stromme P. Magnus P. Kanavin OJ et al. Mortality in childhood progressive encephalopathy from
1985 to 2004 in Oslo, Norway: a population-based study. Acta Paediatr 2008; 97: 35-40.

12. Xu V, Chan H, Lin AP et al. MR spectroscopy in diagnosis and neurological decision-making. Semin Neurol 2008; 28: 407-22.

13. Gilfillan GD, Selmer KK, Roxrud I et al. SLC9A6 mutations cause $\mathrm{X}$-linked mental retardation, microcephaly, epilepsy, and ataxia, a phenotype mimicking Angelman syndrome. Am J Hum Genet 2008; 82: 1003-10

14. Wilcken B, Haas M, Joy P et al. Expanded newborn screening: outcome in screened and unscreened patients at age 6 years. Pediatrics 2009; 124 : e241-8.

15. Hofmann B. Nyfødtscreening - mer skjult tvang? Tidsskr Nor Lægeforen 2010; 130: 291 -3.

16. Pastores GM, Barnett NL. Current and emerging therapies for the lysosomal storage disorders. Expert Opin Emerg Drugs 2005; 10: 891-902.

17. Weinreb NJ, Charrow J, Andersson HC et al. Effectiveness of enzyme replacement therapy in 1028 patients with type 1 Gaucher disease after 2 to 5 years of treatment: a report from the Gaucher Registry. Am J Med 2002; 113: 112-9.

18. Mehta A, Beck M, Elliott $P$ et al. Enzyme replacement therapy with agalsidase alfa in patients with Fabry's disease: an analysis of registry data. Lancet 2009: 374: 1986-96.

19. Cox TM, Aerts JM, Andria G et al. The role of the iminosugar $\mathrm{N}$-butyldeoxynojirimycin (miglustat) in the management of type I (non-neuronopathic) Gaucher disease: a position statement. J Inherit Metab Dis 2003; 26: 513-26.

20. Cox-Brinkman J, van Breemen MJ, van Maldegem BT et al. Potential efficacy of enzyme replacement and substrate reduction therapy in three siblings with Gaucher disease type III. J Inherit Metab Dis 2008; 31: 745-52.

21. Shapiro E, Krivit W, Lockman L et al. Long-term effect of bone-marrow transplantation for childhood-onset cerebral X-linked adrenoleukodystrophy. Lancet 2000; 356: 713-8.

22. Cartier N, Hacein-Bey-Abina S, Bartholomae CC et al. Hematopoietic stem cell gene therapy with a lentiviral vector in X-linked adrenoleukodystrophy. Science 2009; 326: 818-23.

Manuskriftet ble mottatt 7.1. 2010 og godkjent 17.6. 2010. Medisinsk redaktør Siri Lunde. 